\title{
Comparative Performance Assessment of Major Irrigation Systems in Upper Deduru Oya Basin
}

\author{
W.A.S. Lakmali ${ }^{*}$, E.R.N. Gunawardena ${ }^{1}$ and N.D.K. Dayawansa ${ }^{1}$ \\ Postgraduate Institute of Agriculture \\ University of Peradeniya \\ Sri Lanka
}

\begin{abstract}
Performance assessment of irrigation systems plays a vital role to self-evaluate them so that interventions could be made to improve the functioning of the systems. This study was conducted to assess water delivery and supply performances and the agricultural productivity in three major irrigation systems, namely, Batalagoda, Hakwatuna Oya and Kimbulwana Oya in the upper Deduru Oya river basin and comparatively evaluate them based on the estimated values of selected performance indicators. Secondary data were collected from these three systems with respect to rainfall, yield, cultivation performances, water supply and delivery for the period of 2012/2013 Maha and 2013 Yala seasons. The results showed that the relative yield of more than 1.0 was achieved only during Maha season at Batalagoda and Hakwatuna Oya irrigation systems. None of the systems were able to reach the indicative paddy yield of $5 \mathrm{Mt} / \mathrm{ha}$ during the Yala season. The overall comparison of performance indicators during both seasons have shown that the performance of Hakwatuna Oya irrigation system was relatively better compared to Batalagoda irrigation system followed by Kimbulwana Oya irrigation system. The water scarcity during Yala season at Batalagoda and Hakwatuna Oya irrigation systems has resulted lower crop productivity. Irrespective of high relative water supply, the actual yield is much less than the indicative yield during both seasons at Kimbulwana Oya irrigation system. The reasons for poor water and crop productivity during both seasons at Kimbulwana Oya irrigation system needs to be explored in detail so that interventions could be made to improve the system performance.
\end{abstract}

Keywords: Deduru Oya basin, irrigated agriculture, performance assessments, water management, water productivity

\section{INTRODUCTION}

Irrigated agriculture being the major fresh water consumer among the water use sectors is highly threatened under water scarcity situation in the recent past as a result of growing water demands from emerging sectors (Aman, 2003). Effective, efficient and sustainable utilization of water resources are important strategies to cope with water scarcity. According to Mdemu et al. (2008) improving water productivity is one important strategy for addressing future water scarcity. Water productivity is an indicator of agricultural productivity in relation to the crop's consumptive use of water (World Development Report, 2003). Productivity enhancements are accompanied with optimum resource utilization and maximization of the marginal production. Improving water productivity in agriculture reduces competition for scarce water resources, gives solutions to mitigate environmental degradation and finally may leads to enhance food security.

\footnotetext{
1. Department of Agricultural Engineering, Faculty of Agriculture, University of Peradeniya, Sri Lanka

Corresponding author: shyanikalakmali@gmail.com
} 
This high water productivity is one of the important indicators among many which is reflected by the performance of irrigation systems.

Performance assessment of irrigation and drainage is the systematic observation, documentation and interpretation of the management of an irrigation and drainage system, with the objective of continuous improvement (Bos et al., 2005). The bench marking process can be used to highlight the aspects of performance where change is necessary and possible (Cornish, 2005). Leslie and Sevendsen (1990) stated that, many of the irrigation systems in developing countries have been performing far below their potential. Criteria used in performance studies are important for indepth assessment of irrigation systems, while facilitating the operation through better monitoring and controlling (Lin, 2008). International Water Management Institute (IWMI) has proposed minimum set of indicators for comparative performance studies in irrigation systems. They have focused on water, land and crop production in different systems. This cross comparison gives the answer to which irrigation system utilizes limited water and land resources optimally (Molden $e t$ al., 1998). Recent studies have attempted to standardize these indicators to allow for better comparison across systems (Bos et al., 1994). According to Cornish (2005) the selection of indicators for cross comparison has evolved over time and remains fluid, as the users get the experience with collection, analysis and diagnosis of the data.

The investment on large irrigation systems is being done by the Government of Sri Lanka as one of the strategies to alleviate rural poverty while ensuring food security. Even though huge budgetary capital is allocated to construct irrigation infrastructure in the country, most of the systems operate with lower efficiency levels compared to desired levels. In the South Asian region, large scale public surface irrigation systems are performing below their potential due to inappropriate designs and lack of proper operation and maintenance (Hassen, 2004). Negligence of irrigation systems management has been a primary cause for underperformance of irrigation systems (Kotagama et al., 1992). Inefficiencies in irrigation systems create various issues in the national economy while affecting the social cohesion of the society due to water scarcity in terms of irrigation water deficiencies and lower irrigation water reliability. Therefore, it is important to maintain good performance levels in irrigation systems to improve crop productivity to uphold the national economy which is mainly based on agriculture.

Deduru Oya basin is the fourth largest river basin in Sri Lanka and is located within the highly vulnerable areas due to climate change according to recent studies (Katupotha, 2009). As a result, performance of such large irrigation systems within the basin needs to be studied to assess the status of their performances and the underline reasons for such performances so that interventions could be made in advance to address impacts of water scarcity. Therefore, the objective of this study was to assess three major irrigation systems in upper Deduru oya river basin with respect to irrigation water utilization performances for crop production at their system level and to identify reasons for such performances.

\section{METHODOLOGY}

\section{Study site}

This study was conducted in three irrigation systems, namely, Batalagoda, Hakwatuna Oya and Kimbulwana Oya which are located within the upper Deduru Oya river basin (Figure 1). Catchment area of Deduru Oya basin covers $2620 \mathrm{~km}^{2}$ in the wet and intermediate zones with 3\% in Kandy and Matale districts, $88 \%$ in Kurunegala district and 9\% in Puttalam district (Somaratne et al., 2003). The details of the three systems are given in Table 1. 
Batalagoda Irrigation System is situated in $\mathrm{WM}_{3}$ Agro Ecological Region (AER). The annual rainfall is about $1270 \mathrm{~mm}$ in $\mathrm{WM}_{3}$. Rice can be grown in both Yala and Maha seasons. The main soil types of the region are Red Yellow Podzolic soil in undulating terrain, Reddish Brown Latazolic and Immature Brown Earth soils situated in steeply dissected, hilly, and rolling terrain (Katupotha, 2009).
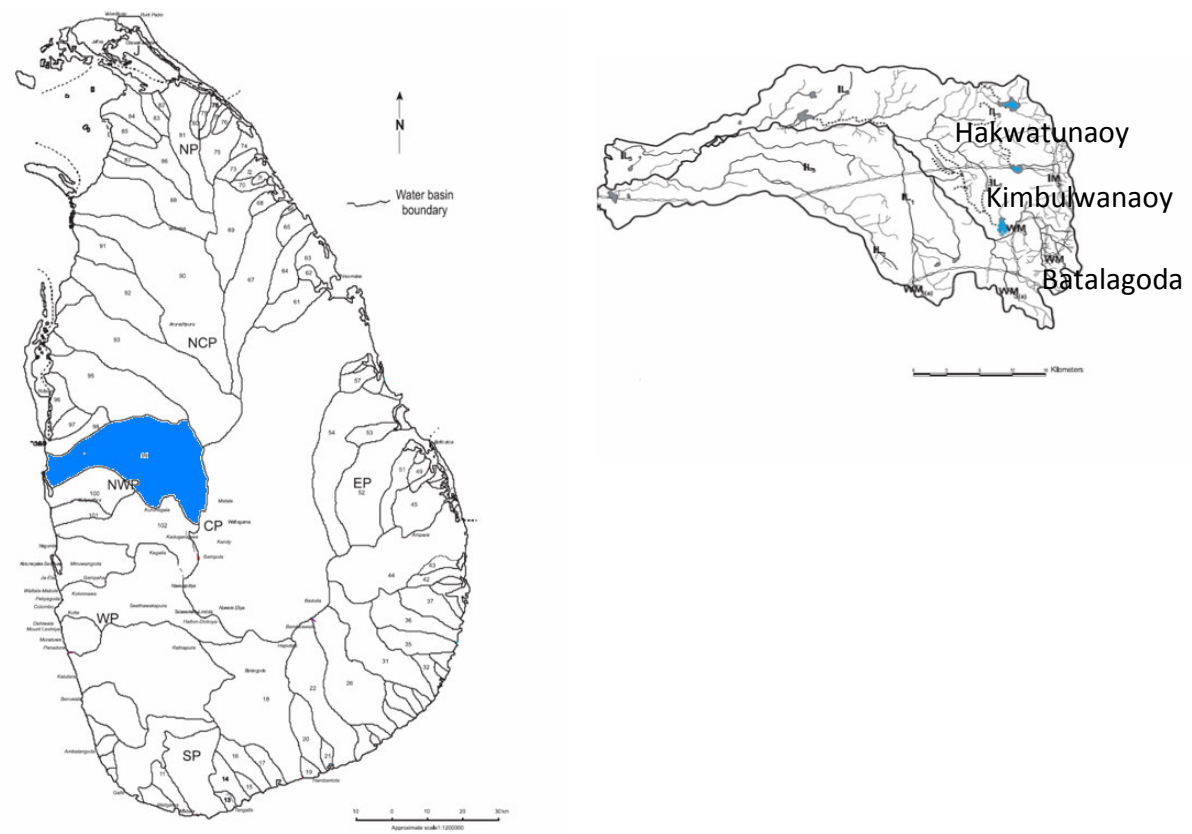

Fig. 1. Location of study area

(Source: Somaratne et al., 2003)

Hakwatuna Oya irrigation system is located in the $\mathrm{IL}_{3}$ region and receives less amount of rainfall compared to other two regions in the intermediate zone. Only October and November months receive rainfall over $200 \mathrm{~mm}$. In this region, some of the loose soils (None Calcic Brown and Alluvial) are used for dry sowing especially during Yala season for maximum use of rain water. The main rice growing soils in this region are Reddish Brown Earths, Low Humid Glay and None Calcic Brown soils situated in undulating terrain (Katupotha, 1992).

The Kimbulwana Oya irrigation system represents $\mathrm{IL}_{1}$ AER. Rainfall pattern during Maha season ensure favorable rice production. However, during Yala season rice production is recommended only with irrigation facility. The major soil types include Low Humid Glay soils situated in undulating to rolling terrain and River Alluvial in flat terrains. Imperfectly drained Red Yellow Podzolic soils with strongly mottled sub soil are also used for paddy cultivation to a certain extent (Katupotha, 1992).

\section{Data collection}

Data used for estimating comparative performance indicators were collected during the period of 2012/2013 Maha and 2013 Yala seasons. Data used for the computation of performance 
indicators for 2012/2013 Maha season and 2013 Yala season are shown in Table 2. Seasonal volumes of irrigation water supply, gross capacities of three systems and paddy yield for the systems were collected using seasonal performance records of each system available at the Residential Project Managers' offices (RPM) of the respective irrigation systems. Rainfall, command area specified by the Irrigation Department, irrigated extent including encroachments and cultivated crop varieties were obtained from the records available at the Divisional Irrigation Engineers Office and verified from relevant RPM offices. Prices of paddy for the above seasons were obtained from RPM office and it was verified by interviewing of farmers. Indicative targets for paddy for major irrigation systems in Kurunegala District for both seasons were obtained from official website of the Ministry of Agriculture. Seepage and percolation loss for three and half month paddy variety on RBE soil and water requirement for land preparation data were adopted from Nayakakorale (1980). Crop water requirement for three and half months paddy varieties for both seasons were taken from Udagedara and Najim (2010).

Table 1 Details of three irrigation systems selected for the study

\begin{tabular}{llll}
\hline Description & Batalagoda & HakwatunaOya & Kimbulwana Oya \\
\hline Agro ecological region & $\mathrm{WM}_{3}$ & $\mathrm{IL}_{3}$ & $\mathrm{IL}_{1}$ \\
Cultivated area (ha) & 3088.7 & 2577.7 & 991.3 \\
Mode of irrigation & Reservoir & Reservoir & Reservoir \\
Specified irrigable area (ha) & 3088.7 & 2093.0 & 665.2 \\
Gross capacity (MCM) & 5.9 & 24.3 & 8.5 \\
Area at FSL (ha) & 244.8 & 333.8 & 267.2 \\
Dead storage (MCM) & 0.2 & 3.7 & 0.5 \\
No. of farmer organizations & 22 & 13 & 13 \\
No. of farmer families & 5450 & 3500 & 1775 \\
\hline
\end{tabular}

$\mathrm{MCM}=$ Million Cubic Meter

FSL $=$ Full Supply Depth

(Personal Communication, 2014)

\section{Data analysis}

\section{Indicators of water delivery and supply performances}

Water delivery and supply indicators are useful to identify the efficiency of the services provided by the system. In view of irrigation systems, irrigation water is the main input for crop production. Hence, water supply performance of the irrigation system can be assessed by computing indicators on input supply aspect for agriculture. Guidelines for benchmarking performance in the irrigation and drainage sector by Malano and Burton (2001) has recommended to use three indicators, as given in Table 3 to assess irrigation service delivery with respect to system operations. The indicator of irrigation contributions shows the percentage of water requirement of the crop met by irrigation water. The relative water supply provides information as to the adequacy of water provided by both irrigation and rainfall to meet the crop water demand (potential crop evapotranspiration plus deep percolation and seepage losses) as defined by Molden et al. (1998). 
Table 2. Supplementary data used for the estimation of performance indicators

\begin{tabular}{|c|c|c|c|c|}
\hline \multirow[b]{2}{*}{ Type of Data } & \multirow[b]{2}{*}{ Season } & \multicolumn{3}{|c|}{ Irrigation System } \\
\hline & & Batalagoda & $\begin{array}{l}\text { Hakwatuna } \\
\text { Oya }\end{array}$ & $\begin{array}{l}\text { Kimbulwana } \\
\text { Oya }\end{array}$ \\
\hline \multirow[t]{2}{*}{ Paddy yield (Mt/ha) } & 2012/13 Maha & 6.19 & 5.93 & 4.12 \\
\hline & 2013 Yala & 3.35 & 4.12 & 3.87 \\
\hline \multirow[t]{2}{*}{ Cultivated variety } & 2012/13 Maha & \multicolumn{3}{|c|}{ Mostly Bg 352} \\
\hline & 2013 Yala & \multicolumn{3}{|c|}{$\begin{array}{l}\text { Mostly Bg } 352 \\
\text { (3.5 Months) }\end{array}$} \\
\hline \multirow{3}{*}{$\begin{array}{l}\text { Indicative paddy yields } \\
\text { from major irrigation } \\
\text { systems (Mt/ha) in } \\
\text { Kurunegala district }\end{array}$} & 2012/13 Maha & \multicolumn{3}{|c|}{5.0} \\
\hline & 2013 Yala & \multirow{2}{*}{\multicolumn{3}{|c|}{5.0}} \\
\hline & & & & \\
\hline \multirow{2}{*}{$\begin{array}{l}\text { Total irrigable area } \\
\text { (ha) }\end{array}$} & 2012/13 Maha & 3091 & 2578 & 991 \\
\hline & 2013 Yala & 3091 & 2578 & 991 \\
\hline \multirow{2}{*}{$\begin{array}{l}\text { Diverted irrigation } \\
\text { water (MCM) }\end{array}$} & 2012/13 Maha & 18.65 & 15.63 & 13.01 \\
\hline & 2013 Yala & 14.29 & 12.34 & 7.70 \\
\hline \multirow{2}{*}{$\begin{array}{l}\text { Effective Rainfall } \\
(\mathrm{mm})\end{array}$} & 2012/13 Maha & 707 & 327 & 461 \\
\hline & 2013 Yala & 381 & 162 & 240 \\
\hline \multirow{2}{*}{$\begin{array}{l}\text { CWR for } 3.5 \text { months } \\
\text { paddy (m) }\end{array}$} & 2012/13 Maha & \multicolumn{3}{|l|}{0.325} \\
\hline & 2013 Yala & \multicolumn{3}{|l|}{0.445} \\
\hline \multicolumn{2}{|l|}{$\begin{array}{l}\text { Seepage and } \\
\text { percolation loss for } \\
3.5 \text { months paddy on } \\
\text { RBE soil (m) }\end{array}$} & \multicolumn{3}{|l|}{0.383} \\
\hline \multicolumn{2}{|l|}{$\begin{array}{l}\text { Water requirement for } \\
\text { land preparation }(\mathrm{m})\end{array}$} & \multicolumn{3}{|l|}{0.163} \\
\hline
\end{tabular}

$\mathrm{CWR}=$ Crop Water Requirement

\section{Indicators for agricultural productivity}

Agricultural productivity is the expected output of the system by utilizing irrigation water. After extensive literature review, six indicators were selected for assessing the productivity in irrigated agriculture as given in Table 4.

Average paddy yield reflects the productivity of land and this particular indicator depends on the scarcity of land resource (Rao, 1993). As an indicator, it gives the information on yield per unit area per season and shows the potential of that land for paddy production under set of environmental and other supplementary input services (Takeuchi and Murty, 1994). The relative yield indicator gives the ability of a particular system to produce over the expected yield at optimum conditions. This is a ratio between actual crop yield of a particular system and expected crop yield of major irrigation systems. When the water is a scarce resource, agricultural productivity per unit water delivered, as indicated by water productivity, gives a good picture on performance of the system with respect to production (Rao, 1993). Land is now becoming a 
limited resource and for comparing irrigation systems output per cropped area can be used as an indicator (Molden et al., 1998). Gross value of production in monetary terms was derived under total water consumption by the system as a whole. The index commonly used in indicating the extent of irrigation is the cropping intensity (Takeuchi and Murty, 1994). This is primary and essential criteria to measure irrigation service performance (Lenselink and Jurriens, 1992).

Table 3. Selected indicators for water delivery and supply performances

\begin{tabular}{|c|c|}
\hline Indicator & Information used \\
\hline Irrigation contribution (\%) & $\begin{array}{l}\text { Amount of irrigation water diverted x } 100 / \text { Total } \\
\text { water requirement for paddy including land } \\
\text { preparation }\end{array}$ \\
\hline $\begin{array}{l}\text { Seasonal irrigation supply per unit } \\
\text { irrigation area }\end{array}$ & $\begin{array}{l}\text { Seasonal volume of irrigation supply/Seasonal } \\
\text { irrigated crop area of the system }\end{array}$ \\
\hline Relative water supply & $\begin{array}{l}\text { Total water supply (IR+RF)/Crop demand (ET+ } \\
\text { Seepage) }\end{array}$ \\
\hline
\end{tabular}

Table 4. Selected performance indicators for agricultural productivity

\begin{tabular}{ll}
\hline $\begin{array}{l}\text { Indicator } \\
\text { (Average paddy yield) }\end{array}$ & \multicolumn{1}{c}{$\begin{array}{c}\text { Information used } \\
\text { (Total paddy yield/Cultivated extent) }\end{array}$} \\
\hline Relative yield & $\begin{array}{l}\text { Actual crop yield/ Expected crop yield from } \\
\text { major irrigation systems (National average for } \\
\text { major irrigation systems, Department of Census } \\
\text { and Statistics) }\end{array}$ \\
Cropping intensity & $\begin{array}{l}\text { Total area cultivated during the season / Total } \\
\text { Command area }\end{array}$ \\
Water productivity & $\begin{array}{l}\text { Total paddy yield per season/ Diverted seasonal } \\
\text { irrigation supply }\end{array}$ \\
Output per cropped area & $\begin{array}{l}\text { Seasonal value of agricultural production/ } \\
\text { Cultivated extent }\end{array}$ \\
Output per unit irrigation water supplied & $\begin{array}{l}\text { Seasonal value of agricultural production/ } \\
\text { Diverted irrigation supply }\end{array}$ \\
\hline
\end{tabular}

\section{RESULTS AND DISCUSSION}

\section{Batalagoda irrigation system}

The water delivery and supply indicators and agricultural productivity indicators for three major irrigation systems studied are given in Table 5. The level of effectiveness of irrigation water 
supply is shown by the three indicators computed for Batalagoda irrigation system. According to the results, $69 \%$ of total water requirement was contributed by irrigation water during Maha season whilst it was $47 \%$ during Yala season. However, there was an adequate water supply to the crop during both seasons as indicated by relative water supply of 1.06 and 1.91 for Yala and Maha seasons, respectively. According to David et al. (2003), relative water supply relates supply to demand and it gives an indication as the condition of water abundance or scarcity, and further, how tightly supply and demand matched. Estimated figures for both seasons indicate the abundance of water in the system during the study period.

Table 5. Comparison of estimated performance indicator values for three major irrigation systems (2012/2013 Maha and 2013 Yala)

\begin{tabular}{|c|c|c|c|c|c|c|}
\hline \multirow{2}{*}{ Performance Indicator } & \multicolumn{2}{|c|}{ Batalagoda } & \multicolumn{2}{|c|}{ Hakwatuna oya } & \multicolumn{2}{|c|}{ Kimbulwana oya } \\
\hline & Yala & Maha & Yala & Maha & Yala & Maha \\
\hline \multicolumn{7}{|c|}{ Water Delivery and Supply } \\
\hline \multirow{2}{*}{$\begin{array}{l}\text { Irrigation contribution }(\%) \\
\text { Seasonal irrigation supply } \\
\text { per unit irrigation area } \\
\left(\mathrm{m}^{3} / \mathrm{m}^{2}\right)\end{array}$} & 47 & 69 & 48 & 70 & 79 & 151 \\
\hline & 0.46 & 0.60 & 0.48 & 0.61 & 0.78 & 1.31 \\
\hline Relative water supply & 1.06 & 1.91 & 0.79 & 1.34 & 1.23 & 2.50 \\
\hline \multicolumn{7}{|l|}{ Agricultural Productivity } \\
\hline \multirow[t]{2}{*}{ Paddy yield (Mt/ha) } & 3.35 & 6.19 & 4.12 & 5.93 & 3.87 & 4.12 \\
\hline & 100 & 100 & 100 & 100 & 100 & 100 \\
\hline Cropping intensity (\%) & $*(100)$ & $*(100)$ & $*(123)$ & $*(123)$ & $*(149)$ & $*(149)$ \\
\hline Relative yield & 0.7 & 1.2 & 0.8 & 1.2 & 0.8 & 0.8 \\
\hline $\begin{array}{l}\text { Water productivity } \\
\left(\mathrm{kg} / \mathrm{m}^{3}\right)\end{array}$ & 0.72 & 1.03 & 0.86 & 0.98 & 0.50 & 0.31 \\
\hline $\begin{array}{l}\text { Output per cropped area } \\
\text { (Rs }(, 000) / \text { ha) }\end{array}$ & 107.18 & 173.14 & 131.92 & 165.93 & 123.67 & 115.43 \\
\hline $\begin{array}{l}\text { Output per unit irrigation } \\
\text { water supplied }\left(\mathrm{Rs} / \mathrm{m}^{3}\right)\end{array}$ & 23.19 & 28.70 & 27.57 & 27.39 & 15.91 & 8.80 \\
\hline
\end{tabular}

Paddy 1 busal $/ \mathrm{ac}=51.55 \mathrm{kgs} / \mathrm{ha}$ and paddy 1 busal $=20.87 \mathrm{kgs}$ (Conversion rates adopted from Central Bank of Sri Lanka) ; * Total area cultivate by the system/Specified irrigable area

Though, there was adequate water supply, the actual yield $(3.35 \mathrm{Mt} / \mathrm{ha})$ was less than the indicated yield of $5 \mathrm{MT} /$ ha during Yala season as shown by relative yield of 0.7. The output was much better during the Maha season with a paddy yield of $6.19 \mathrm{Mt} / \mathrm{ha}$ and relative yield of 1.3. This could be explained by examining the rainfall contribution during both seasons. The effective rainfall during 2012/2013 Maha was around $706 \mathrm{~mm}$ whilst it was $381 \mathrm{~mm}$ for 2013 Yala. Though, the total irrigation and rainfall contribution during the Yala season was just adequate to provide the crop water demand, as shown by relative water supply of 1.06 , there may have been spatial and temporal water scarcity during the season, leading to crop water stress. In contrast, the water availability to the crop during Maha was $91 \%$ more (since relative water supply is 1.91) than what was required and hence provided a much better output of $6.19 \mathrm{Mt} / \mathrm{ha}$. Nayakkorale (1980) reported that most of the crop water requirement could be met by rainfall during Maha season by adhering to proper planting dates and preventing any possible moisture stress by 
supplementary irrigation. Upasena et al. (1990) also argued that, evapotranspiration requirement of rice crop is usually met by the rainfall received in the dry zone during Maha season unless there is an exceptional drought.

The higher water productivity during Maha season (1.03) compared to Yala season (0.72) is due to percentage increment of water supply along with higher paddy production during 2012/2013 Maha season. It is also reflected by the higher value of production per unit irrigation water

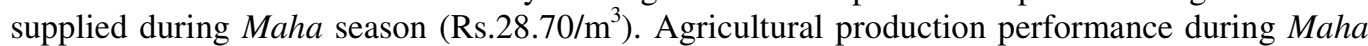
season was confirmed by the observable difference for output per cropped area which is estimated for these two seasons.

It was observed that the physical irrigation infrastructure in this system has deteriorated over time. In addition, there were no field canals for every paddy plots. This has led to inadequate water supply for tail-end farmers, especially during the Yala season. Therefore, rehabilitation of the irrigation system is a prime need in order to improve the performance of the Batalagoda irrigation system.

\section{Hakwatuna oya irrigation system}

Hakwatuna Oya irrigation system follows the same trend for estimated performance indicator values during Yala and Maha seasons as Batalagoda irrigation system. For instance, Hakwatuna Oya irrigation system was able to maintain about the same level of irrigation contribution as Batalagoda irrigation system. The notable differences are higher paddy yield during Yala season and the higher output for unit irrigation water supplied in terms of rupees per $\mathrm{m}^{3}$. Comparatively higher relative yield during Yala season and higher water productivity gave more value of production for Hakwatuna Oya irrigation system than that of Batalagoda irrigation system.

Paddy productivity at Hakwatuna Oya irrigation system was $4.12 \mathrm{Mt} / \mathrm{ha}$ and $5.93 \mathrm{Mt} / \mathrm{ha}$ in Yala and Maha seasons, respectively. The relative yields of corresponding seasons were 0.8 and 1.2. Percentage paddy production increment during 2012/2013 Maha season compared to 2013 Yala season was $50 \%$. These production enhancements might be due to higher contribution from both rainfall and irrigation during Maha season. According to Table 4, irrigation contribution and seasonal irrigation supply per unit irrigation area is higher in Maha season than that of Yala season. Paddy productivity in Hakwatuna Oya irrigation system is closely associated with the productivity of soil. Low Humic Glay soil has good texture and mineralogical composition for agricultural crops. Panabokke, (1996) revealed that, rice yields of $4.0 \mathrm{Mt} / \mathrm{ha}$ are easily attainable on this type of soil when the irrigation supply is not limited. This might be the reason for better paddy productivity reported for Hakwatuna Oya irrigation system even though with the limited water supply.

Somaratne et al. (2003) has identified Batalagoda as moderately water abundant system and Hakwatuna Oya as a water scarce system. This observation is confirmed by low relative water supply values estimated for Hakwatuna Oya irrigation system compared to Batalagoda irrigation system in both seasons. According to Somaratne et al. (2003) Hakwatuna Oya system recorded the highest output per unit water. The similar result was obtained in this study as well. That shows the effective utilization of scarce water resource within the irrigation system by the farmers in Hakwatuna Oya irrigation system. It is to be noted that the actual cultivated area is higher than the specified irrigable area for Hakwatuna Oya system due to encroachments. That may be one of the reasons for limited water supply for all paddy lands in this system during the Yala season. 
Evidences for higher water productivity during Yala season were gathered during the discussions with the farmers in Hakwatuna Oya irrigation system. The main reason behind the higher return per unit of water is primarily due to the participation of farmers in system management activities through their Water Use Association (WUA). This performance of the WUA is guided by their Residential Project Manager in Hakwatuna Oya irrigation system. In addition, farmers usually expect water scarcity in every season which motivates them to utilize water sparingly for paddy cultivation. The majority of the farmers in Hakwatuna Oya irrigation system solely depend on paddy cultivation as their livelihood, and as a result they are much more committed to get involved with water management.

\section{Kimbulwana oya irrigation system}

Kimbulwana Oya irrigation system has the lowest productivity of $4.12 \mathrm{Mt} / \mathrm{ha}$ compared to other two systems during Maha season as shown in Table 4. This is less than the indicative crop yield as shown by the relative yield of 0.85 . The productivity value during the Yala season is between the values reported from other two systems.

Water was more than adequate for the system during both Yala and Maha seasons as indicated by the relative water supply of 1.23 and 2.50 , respectively. It is important to note that these higher relative water supply values were obtained irrespective of providing irrigation water to $49 \%$ of additional (encroached) lands. According to Somaratne et al. (2003) Kimbulwana Oya is the most water abundant major irrigation system within Deduru oya river basin. This was found to be valid according to the results obtained in this study as well. This higher water abundance is also reflected by the highest irrigation contribution of 79\% and 151\% during Yala and Maha seasons, respectively. This has resulted lowest output per unit of irrigation water supplied, i.e. Rs $15.91 / \mathrm{m}^{3}$ for Yala season and Rs $8.80 / \mathrm{m}^{3}$ for Maha season. All these performance indicators have shown that the agricultural productivity as well as water supply and delivery performance are the poorest at Kimbulwana Oya irrigation system compared to other two systems studied.

The predominant soil type in this system is Low Humic Glay soil and River Alluvial. Both soil types have higher production potential with respect to paddy cultivation. According to Panabokke (1996), 5.6 Mt/ha paddy yield is attainable with reliable irrigation supply. However, the system did not achieve such a good performance even though it is already associated with fertile soil and reliable water supply. Therefore, further studies are required to find the reasons for such lower land and water productivity.

The relative water supply of three systems studied is comparable with previous studies carried out in Sri Lanka. Dissanayaka, (2009) has conducted a study in Mahaweli system C and the relative water supply was estimated to be between 1.37-1.70 within irrigation blocks.

\section{Limitations and usefulness of the present study}

The agricultural productivity and water supply indicators show the performance of each irrigation systems in addition to the comparisons that could be made. This could be considered as a first step in a diagnostic analysis to identify the problematic areas which need interventions. However, detail studies are required to fully comprehend the reasons of poor performance. The rainfall during 2012/2013 Maha in three irrigation systems could satisfy substantial portion of the crop water requirement of three and half month's paddy variety. Therefore, irrigation water issued from the reservoir during Maha season could be considered as supplementary water to meet the inefficiencies of water distribution within the system. The rainfall recorded within three irrigation systems during 2013 Yala season is not adequate to supply total crop water requirement for 
paddy. Relative water supply of 0.79 at Hakwatuna oya irrigation system shows that the paddy crop at Hakwatuna Oya irrigation systems was under water stress conditions during the Yala season. It could be argued that water shortage during Yala season in three irrigation systems would have been avoided if irrigation water was efficiently used during the previous Maha season leading to the higher water availability at the respective reservoirs at the beginning of Yala season.

Availability of water itself does not guarantee a higher productivity as shown by the relative yield indicators for Kimbulwana Oya irrigation system during both seasons. There was excess irrigation water issued during both seasons as indicated by a relative water supply of more than 1.0. Therefore, some other reasons may have contributed to the low productivity which needs indepth studies.

\section{CONCLUSIONS}

The results showed that the relative yield of more than 1.0 was achieved only during Maha season at Batalagoda and Hakwatuna Oya irrigation systems. None of the systems were able to reach the indicative paddy yield of $5 \mathrm{Mt} /$ ha during the Yala season. The overall comparison of performance indicators during both seasons have shown that the performance of Hakwatuna Oya irrigation system was relatively better compared to Batalagoda irrigation system followed by Kimbulwana Oya irrigation system. The water scarcity during Yala season at Batalagoda Irrigation system and Hakwatuna Oya irrigation system has resulted lower productivity. Irrespective of very high relative water supply, the actual yield is much less than the indicative yield during both seasons at Kimbulwana Oya irrigation system. The reasons for poor water and crop productivity during both seasons needs to be explored in more details so that interventions could be made to improve the system performances at Kimbulwana Oya irrigation system.

\section{ACKNOWLEDGEMENTS}

The authors wish to express their gratitude to Ms. Samanthi Jayamanne, Engineer, Divisional Irrigation Office, Hiriyala for providing information for this research. Our sincere thanks are also due to all government officials in Irrigation Department, Department of Agrarian Development and Department of Agriculture and farmers for their support during the field work.

\section{REFERENCES}

Aman, M. (2003). Evaluating and comparing the performances of different irrigation systems using remote sensing and GIS, International Institute for Geo-Information Science and Earth Observations, The Netherlands.

Bos, M.G., Rust, H.M., Merry, D.J., Johnson, H.G. and Snellens, W.S. (1994). Methodologies for assessing performance of irrigation and drainage management, Irrigation and Drainage system, 7, $231-261$.

Bos, M.G., Burton, M.A. and Molden, D.J. (2005). Irrigation and drainage performance assessment practical guidelines, International Water Management Institute, Colombo, Sri Lanka. 
Cornish, G.A. (2005). Performance benchmarking in the irrigation and drainage sector, Department of International Development, United Kingdom.

David, M., Rust, H. M., Sakthivadivel, R. and Makin, I. (2003). A Water productivity framework for understanding and action, International Water Management Institute, Colombo, Sri Lanka.

Dissanayaka, S.H. (2009). Assessment of irrigation performance of Mahaweli system-C, Sri Lanka with comparative performance indicators, M.Phil thesis, Postgraduate Institute of Agriculture, University of Peradeniya, Sri Lanka.

Hassen, Y.K. (2004). Assessment of small scale irrigation using comparative performance indicators on two selected irrigation system in Upper Awash River Valley, Alemaya University.

Katupotha, J. (1992). Geomorphic surfaces of the river basins along the Western and Southern Parts of Sri Lanka, NARESA.

Katupotha, J. (2009). Water shortage in lower Deduru oya Basin, National Conference in Water, Food Security and Climate Change, Sri Lanka.

Kotagama, H.B., Smith, L. and Carruthers, I.D. (1992). Identification and estimation of priority weights of irrigation systems management objectives for irrigation system performance assessment, University of Peradeniya, Kandy, Sri Lanka.

Lenselink, K.J. and Jurriens, J. (1992). Inventory of irrigation software for microcomputers. International Institute for Land Reclamation and Improvements, Wageningen, The Netherlands.

Leslie, E.S. and Sevendsen, M. (1990). A framework for assessing irrigation performance , Irrigation and drainage systems, 4, $283-312$.

Lin, D. (2008). Performance evaluation of participatory irrigation management by the supply chain balanced scorecard approach, Copenhagen University, Denmark.

Malano, H. and Burton, M. (2001). Guidelines for benchmarking performance in the irrigation and drainage sector, International program for technology and research in the irrigation and drainage, International Program for Technology and Research in Irrigation and Drainage Secretariat, Food and Agriculture Organization of the United Nations, Rome.

Mdemu, M.V., Rodgersa, C., Vleka, P.L.G. and Borgadi, J.J. (2008). Water productivity (WP) in reservoir irrigated irrigation system in the upper east region (UER) of Ghana.

Molden, D.,Sakthivadivel, R., Perry,C., De Fraiture, C. and Kloezen, W. (1998). Indicators for comparing performance of irrigated agricultural systems, Research Report 20, International Water Management Institute, Colombo, Sri Lanka.

Nayakakorale, H.B. (1980). Supplementary irrigation requirement for early grown lowland rice during the rainy season in dry zone, Regional Research Centre, Maha Illuppallama, Sri Lanka.

Panabokke, C.R. (1996). Soils and agroecological environment of Sri Lanka, Natural resource series-2, Natural Resources and Energy Authority of Sri Lanka. p163. 
Personal Communication (2014). Irrigation Engineer, Divisional Irrigation Engineers' Office, Hiriyala Division.

Rao, P.S. (1993). Review of Selected literature on indicators of irrigation performance, International Water Management Institute, Colombo, Sri Lanka.

Somaratne, P. G., Jinapala, K., Perera, L. R., Ariyaratne, B. R., Bandaragaoda, D. J. and Makin, I. (2003). Developing effective institutions for water resources management: A case study in the DeduruOya Basin, Sri Lanka.International Water Management Institute, Colombo, Sri Lanka.

Takeuchi, K. and Murty, V.V.N. (1994). Land and water development for agriculture: In the Asia-Pacific region. Oxford and IBH Publishing Private Limited, New Delhi.

Udagedara, U.S.C. and Najim, M.M.M. (2009). Potential to increase the area under paddy cultivation with domestic and municipal wastewater irrigation in Kurunegala District, 157-167. In: Evans, A. and Jinapala, K. (Ed.). Proceedings of the National Conference on Water, Food Security and Climate Change in Sri Lanka, BMICH, Colombo, June 9-11, 2009, Volume 2. Water Quality, Environment and Climate Change.

Upasena, S.H., Sikurajapathy, M. and Seneviratna, T. (1990). New cropping system strategy for the poorly irrigated rice lands of the dry zone, Regional Research Centre, Maha Illuppallama, Sri Lanka.

World Development Report (2003). Sustainable Development in a Dynamic World: Transforming Institutions, Growth, and Quality of Life, World Bank. 